\title{
Ethnobotanical studies of fodder grass resources for ruminant animals, based on the traditional knowledge of indigenous communities in Central Punjab Pakistan
}

\author{
Nidaa Harun ${ }^{1,2}$, Abdul Shakoor Chaudhry², Shabnum Shaheen ${ }^{1 *}$, Kifayat Ullah ${ }^{3}$ and Farah Khan ${ }^{1}$
}

\begin{abstract}
Background: Traditional knowledge of indigenous plants is pivotal in developing strategies to feed livestock sustainably in low input systems. Likewise, in Pakistan the indigenous people of Central Punjab have been using their regional grasses as a ruminant fodder for centuries. This study evaluated the indigenous traditional knowledge to ascertain the value of various fodder grasses to optimise their use to feed livestock in Central Punjab.

Methods: The snowball technique was employed to identify key informants who had relevant knowledge about different grasses in the study area. Semi-structured questionnaires, face-to-face interviews and site visits were used for describing the fodder grasses. The data were then analysed by using relative frequency citation and pairwise comparison methods to determine the order of priority among the listed fodder grasses. Furthermore, SPSS 22 software was used for descriptive statistics and interpretation of associations among studied parameters. Microsoft Excel was used to present data as \% values and graphs.

Results: Overall, 53 grasses were described with ethnobotanical information regarding their uses for fodder, ethnoveterinary and other purposes. All these grasses belonged to the family Poaceae where the subfamily Panicoideae had the maximum number of 30 grasses. We categorized these grasses into high (A), medium (B) and low priority (C) groups where the group A grasses were reported as not only the most abundant but also the most palatable forages to all ruminants. Their higher demand was reflected by the feeding systems of both ad libitum grazing and feeding after cutting and mixing with other feeds. The study also revealed 37 previously unreported ethnoveterinary uses of these grasses.

Conclusions: The results have reinforced the value of conserving ethnobotanical knowledge, being poorly documented previously, in developing strategies to feed livestock. It indicated the preferred fodder grasses as well as the possible reasons of their preference. The reported data need to be validated for nutritional and health benefits. This information could help the smallholder farmers in association with regional governments to propagate suitable fodder grasses for their use in sustainable livestock feeding to produce safe and healthy food for indigenous communities.
\end{abstract}

Keywords: Traditional knowledge, Central Punjab, Fodder grasses, Ruminants

\footnotetext{
*Correspondence: shabnumshaheen78@hotmail.com

'Department of Botany, Lahore College for Women University, Lahore 54000,

Pakistan

Full list of author information is available at the end of the article
} 


\section{Background}

The agriculture and livestock industry are playing a predominant role in Pakistan's economy. Around 43.5\% individuals are linked with this industry with its $21 \%$ contribution in Gross Domestic Product (GDP). In this sector the most protuberant role has been made by the Punjab province in comparison to all other provinces of Pakistan [1].

Geographically Punjab is subdivided into south, north, west and central regions [2]. Amongst all the regions of Punjab the Central region is primarily involved in the production of milk and meat from ruminants. Although this area is blessed with diversified fodders (trees, shrubs, herbs and grasses), grasses are conventionally the most common and reliable fodder source for ruminant animals. The indigenous people prefer to use grass as a fodder because grasses are observed to be more palatable than shrubby fodders by ruminant animals [3-6]. Moreover the grasses have massive growth abilities around different seasons and these are conveniently more accessible. Therefore, this study aimed to provide comprehensive information on the traditionally used fodder grasses of Central Punjab Pakistan.

Indigenous communities which have been involved in livestock handling possess a significant knowledge about potential forage resources [7]. Many countries (e.g. India, Ethiopia, Nigeria, Mexico, China and Uganda) around the world understand the worth of this traditional knowledge and therefore they had documented this classic data about fodder plants from various ethnic groups [7-10]. Even in Pakistan multiple ethnobotanical studies have been carried out in different cities of Central Punjab but the previous studies were more focussed on the ethnomedicinal values rather than the fodder significance of indigenous plants. Additionally, these studies seemed to be mostly engaged with fodder trees, herbs or shrubs and not with grasses [11-15]. However grasses are one of most promising fodder resources of this region. While a few ethnobotanical studies involving grasses were conducted in some regions of Pakistan, their main focus was to evaluate the significance of those grasses for human health [16]. Inadequate records about the traditionally used fodder grasses of this region indicated the vulnerability of particular traditional knowledge to being vanished and overlooked Therefore it is crucial to manuscript this traditional knowledge about the preference for fodder grasses by the rural communities of Central Punjab, Pakistan.

This ethno botanical survey based study not only aimed to describe many traditionally used fodder grasses but also to set out an order of priority on the basis of their usage for different ruminant animals. The study also evaluated the relative abundance, medicinal worth, delectableness, and feeding systems of these grasses for ruminants.

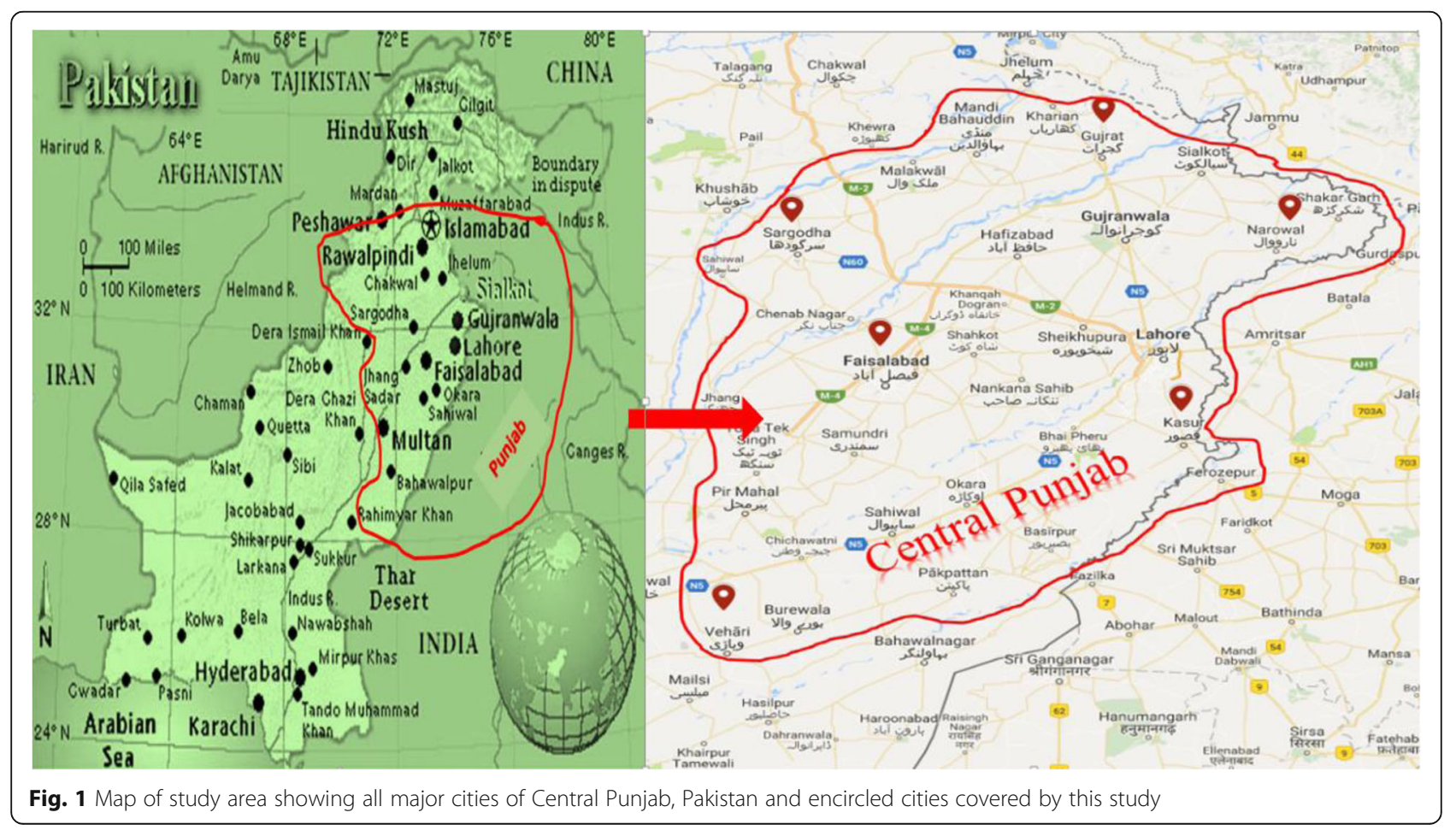




\section{Methods}

\section{Study area}

The southern boundary of River Jhelum down to River Sutlej surrounds the planes of Central Punjab. This region is comprised of 19 districts which are grouped into 3 agro-ecological zones. Among these 3 zones 6 representative cities i.e. Kasur, Faisalabad, Vehari (Northern irrigated zone), Sargodha (Sandy deserts zone), Gujrat, and Narowaal (Barani zone) were selected. As the northern irrigated zone is the largest zone, maximum numbers of 3 targeted areas were selected from it. These areas are not only the main producers of ruminant milk and meat but also these are distantly apart from each other which helped the collection of diversified ethnobotanical data from this region. In these districts, the remote rural areas were actually targeted due to their reliance on conventional fodder grasses as a feed for raising their ruminant animals (Fig. 1).

\section{Ethnobotanical survey and data collection}

The primary goal of this survey was to collect ethnobotanical information about fodder grasses from local ruminant caretakers. Before collecting the data, formal ethical permission was obtained from the chairperson of local government and individual informants of selected study areas. The data were collected between the months of March 2014 to February 2015 from remote and less developed villages of targeted cities. A total of 137 informants were chosen by employing snowball sampling technique. The informants included male and female village leaders, shepherds, ruminant caretakers who worked in indigenous farms and some senior domestic animal caretakers in each of the selected areas (Table 1). Group discussions and individual ethnobotanical semi-structured interviewing techniques were used for data collection [17, 18]. The questionnaires were constructed in English. However, for ease in communicating with the local people during

Table 1 Demography of informants of this study area

\begin{tabular}{|c|c|c|c|c|}
\hline \multirow[t]{2}{*}{ Type of Informants } & $\begin{array}{l}\text { Young } \\
\text { aged }\end{array}$ & $\begin{array}{l}\text { Middle } \\
\text { aged }\end{array}$ & Seniors & \multirow[t]{2}{*}{ Tota } \\
\hline & $25-35$ years & $36-50$ years & $51-65$ years & \\
\hline $\begin{array}{l}\text { Local shepherds } \\
\text { (Female) }\end{array}$ & 2 & 5 & 0 & 7 \\
\hline Local shepherds (Male) & 13 & 23 & 7 & 43 \\
\hline $\begin{array}{l}\text { Farmed Ruminant } \\
\text { care takers (Female) }\end{array}$ & 2 & 4 & 3 & 9 \\
\hline $\begin{array}{l}\text { Farmed Ruminant } \\
\text { care takers ((Male) }\end{array}$ & 9 & 11 & 3 & 23 \\
\hline $\begin{array}{l}\text { Domestic Ruminant } \\
\text { care takers (Female) }\end{array}$ & 11 & 15 & 8 & 34 \\
\hline $\begin{array}{l}\text { Domestic Ruminant } \\
\text { care takers (Male) }\end{array}$ & 6 & 12 & 3 & 21 \\
\hline Total informants & 43 & 70 & 24 & 137 \\
\hline
\end{tabular}

Table 2 Abundance categories and scale of reported grasses

\begin{tabular}{lll}
\hline Abundance scale & Abundance categories & Coverage of grass species \\
\hline+ & Rare (R) & $<5 \%$ \\
1 & Occasional (O) & $5-20 \%$ \\
2 & Frequent (F) & $20-50 \%$ \\
3 & Common (C) & $50-90 \%$ \\
4 & Abundant (A) & $90-100 \%$ \\
\hline
\end{tabular}

interviews and group discussions their indigenous language (different dialects of Punjabi) was used and the answers were translated back to English. The questionnaire included the following questions: (1) Which fodder grasses are most likely to be fed to their ruminant animals? (2) What is the palatability of their chosen grasses? (3) Which part did the animals consume? (4) What are their feeding mode, were they free grazing alone or supplemented or offered as cut grass mixed with other feeds? (5) Do the listed fodder grasses have any ethno veterinary use? (6) What are their other indigenous uses apart from the fodder and ethno veterinary uses?

\section{Fodder grass sampling and authentication}

For the identification and collection of fodder grass samples, several site visits were made with some knowledgeable indigenous people. They helped the surveyor in identification and collection of particular fodder grass from its habitat. The details of each specimen i.e. date of collection; habitat, local names and flowering periods were also recorded during each site visit.

After their collection, each fodder grass sample was identified by comparing their morphological characters with already available grass specimens in the herbariums of Lahore College for Women University, Lahore and the Quaid i Azam University, Islamabad. Along these two herbaria, online available plant databases like flora of Pakistan (http://www.efloras.org/index.aspx), flora of India (https://sites.google.com/site/efloraofindia/) and some other grass flora identification keys [19, 20] were also consulted for their identification and authentication. Afterward the voucher numbers were allotted to all specimens, which were then submitted to the Botany Herbarium of Lahore College for Women University (LCWU).

\section{Estimation of relative abundance}

The most commonly used method of visual assessment was employed for measuring the relative abundance of ethnobotanically enlisted grass species in study area [21]. In this method number of plots randomly selected in study area and the presence of each listed species were counted and recorded. Afterwards percentage relative abundance was calculated by using the following formula; 
Table 3 Template of comparative matchup chart used for pairwise comparison for different grasses

\begin{tabular}{|c|c|c|c|c|c|c|}
\hline Fodder grasses & Species A & Species B & Species C & Species D & Species E & Total votes \\
\hline \multicolumn{7}{|l|}{ Species A } \\
\hline \multicolumn{7}{|l|}{ Species B } \\
\hline \multicolumn{7}{|l|}{ Species C } \\
\hline \multicolumn{7}{|l|}{ Species D } \\
\hline Species E & & & & & & \\
\hline
\end{tabular}

Relative abundance of species

$$
=\frac{\text { Total percentage Cover of species in all plots }}{\text { Number of plots estimated }} \times 100
$$

The species were then grouped into different categories i.e. Abundant, Common, Frequent, Occasional and Rare (ACFOR) by using relevant scales of abundance (Table 2).

\section{Data analysis}

All the recorded data values were tabulated by using Microsoft excel 2013. Two data analysis methods i.e., Relative Frequency of Citation and Pairwise comparison method were applied to find out the priority order of their grass utilization as described below:

a) Relative frequency of citation (RFC)

This tool helped us to set up the priority order among the listed fodder grasses. Its value depended upon the numbers of respondents that had mentioned a particular grass species as a good fodder indicating its significance. The RFC was estimated by using the following eq. [22].

$$
\mathrm{RFC}=\mathrm{FC} / \mathrm{N}(0<\mathrm{RFC}<1)
$$

where
$\mathrm{FC}=$ number of respondents who stated that particular grass species as a good fodder, $\mathrm{N}=$ total number of respondents included in study

b) Pairwise comparison method (PC)

In combination to RFC another data analysis tool called PC method was also employed to establish a priority order among listed fodder grasses [23]. In this method a comparative matchup chart (Table 3) was constructed between different fodder grasses and then each informant was asked to vote their preferable fodder grass among those. Each species got 1 point if the respondents preferred it over the other fodder grass. The half point was allotted to each of them if they were ranked equal by the respondents. Finally, all points were added for each grass species to predict their priority order of utilization.

c) Cluster analysis \& descriptive Statistics

For making groups of high and low priority fodder grasses, Hierarchical Cluster Analysis (Squared Euclidean distance method) in the SPSS 22 software was applied to the RFC values. Moreover, descriptive statistical analysis (frequency and cross tabulation) was also employed to find out the association between different parameters of the survey.

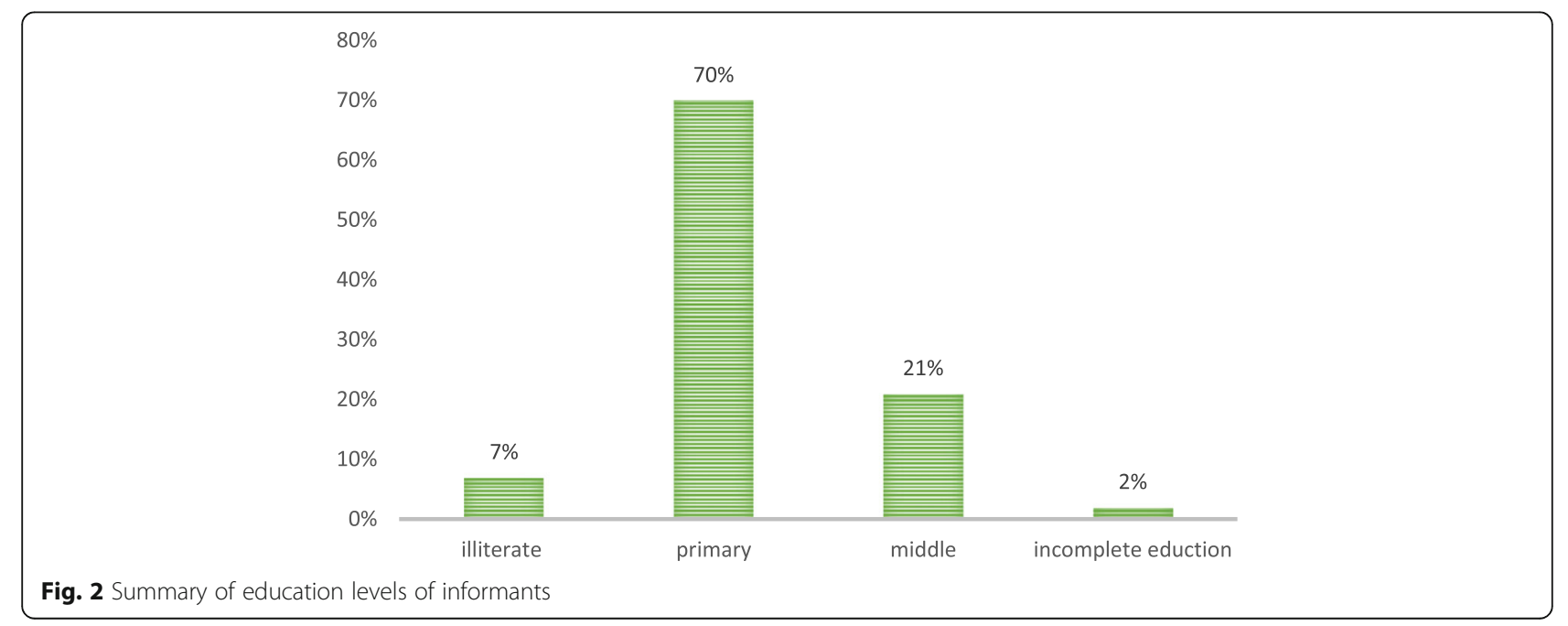




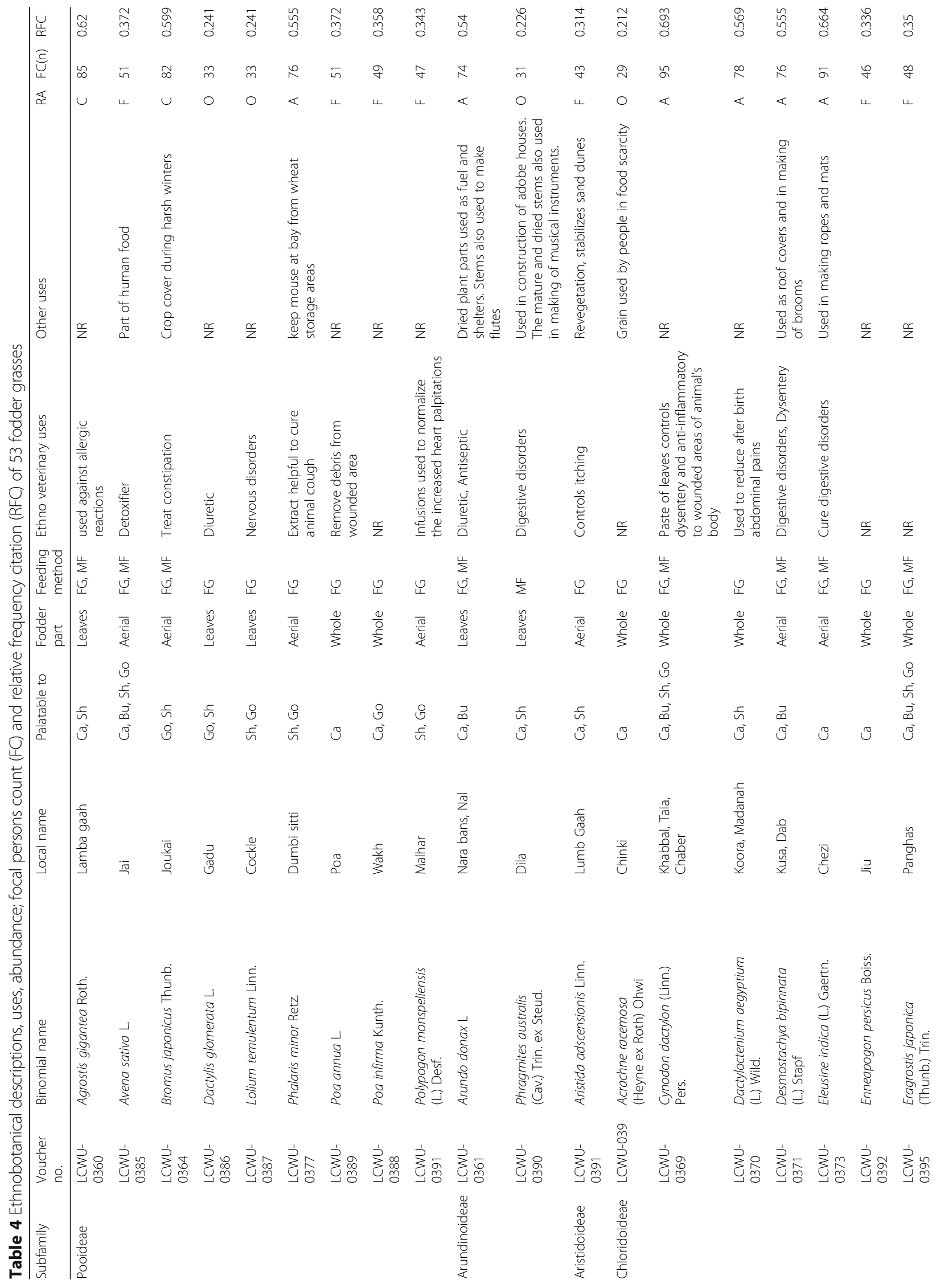




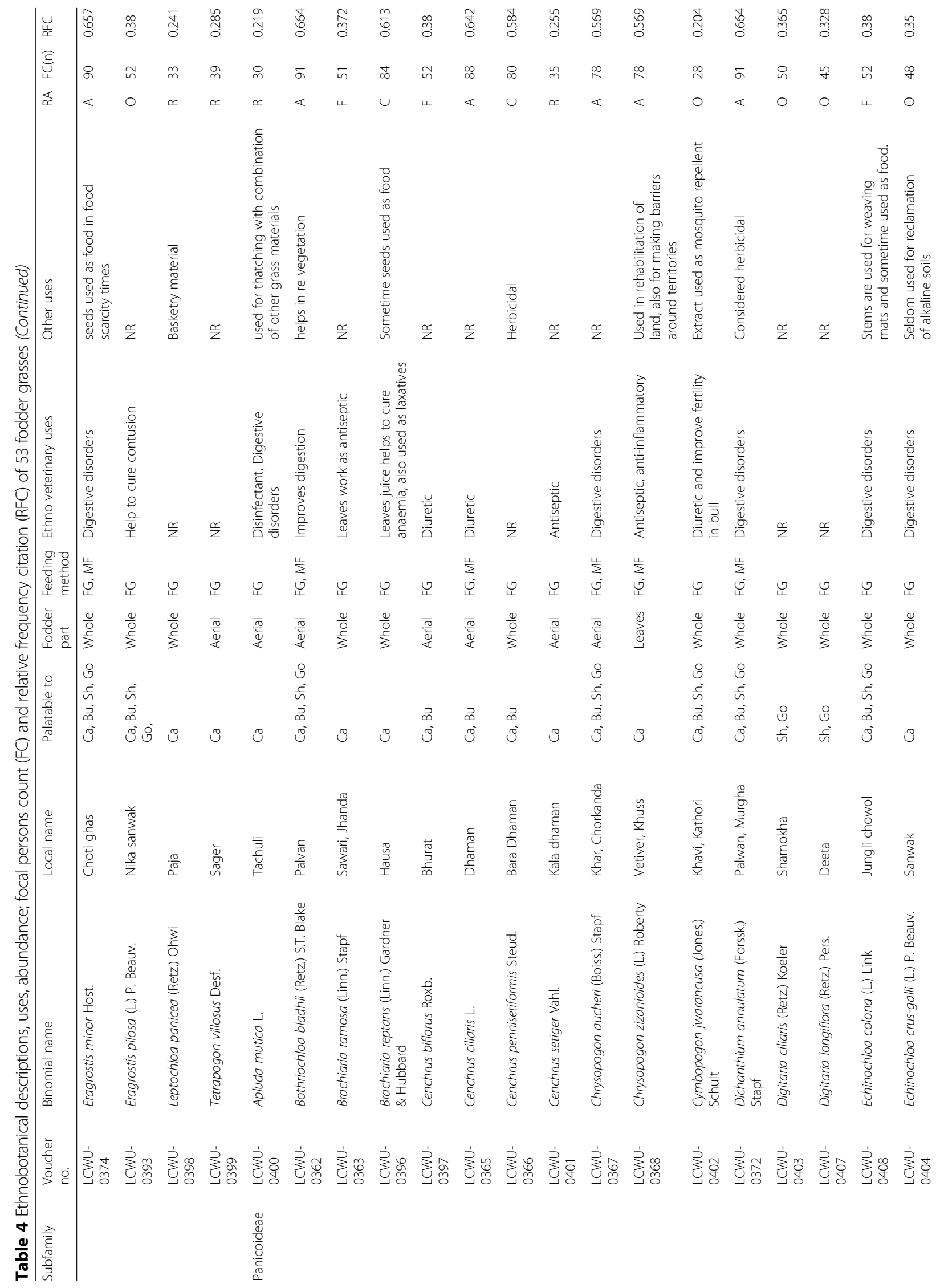




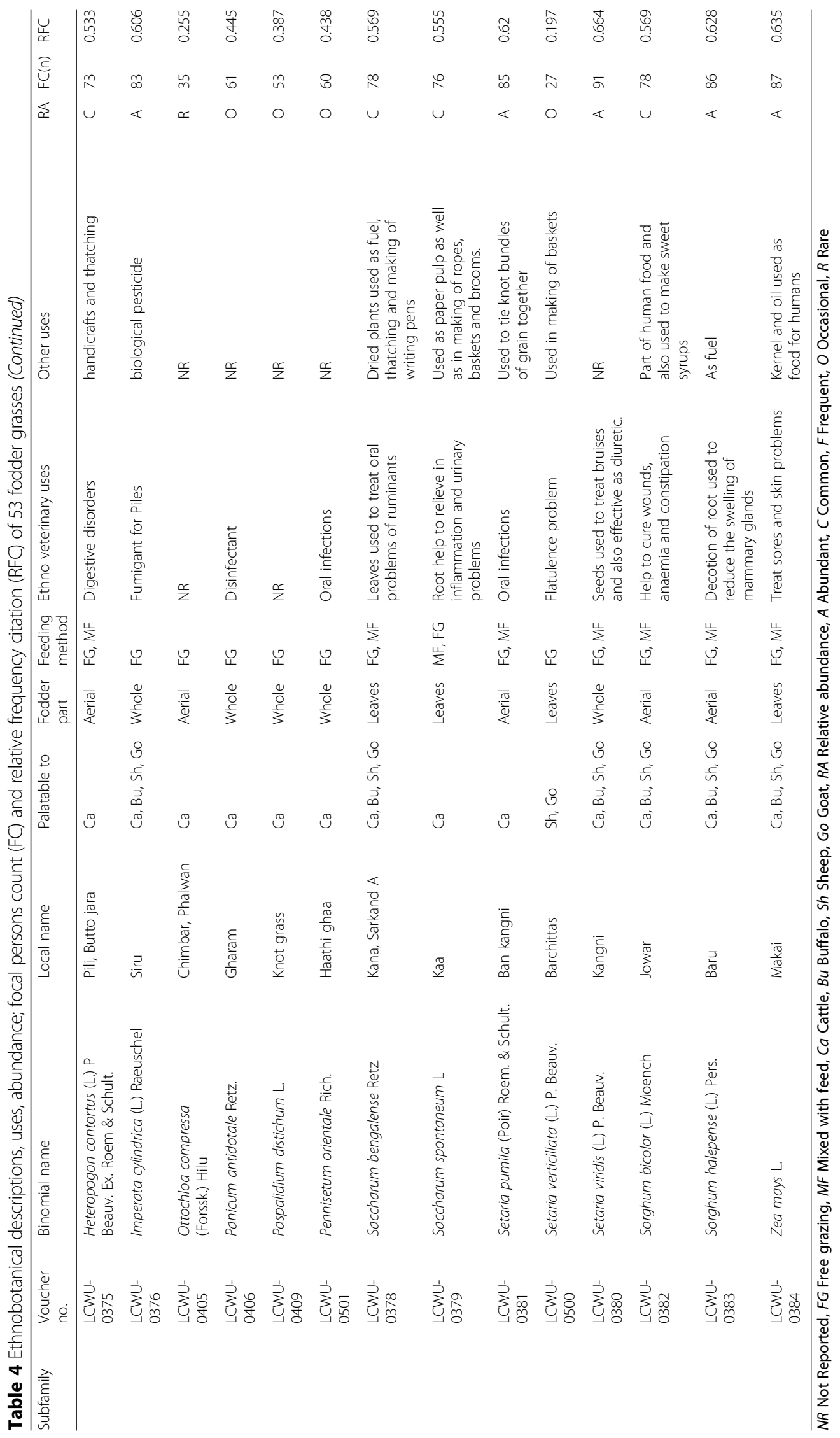




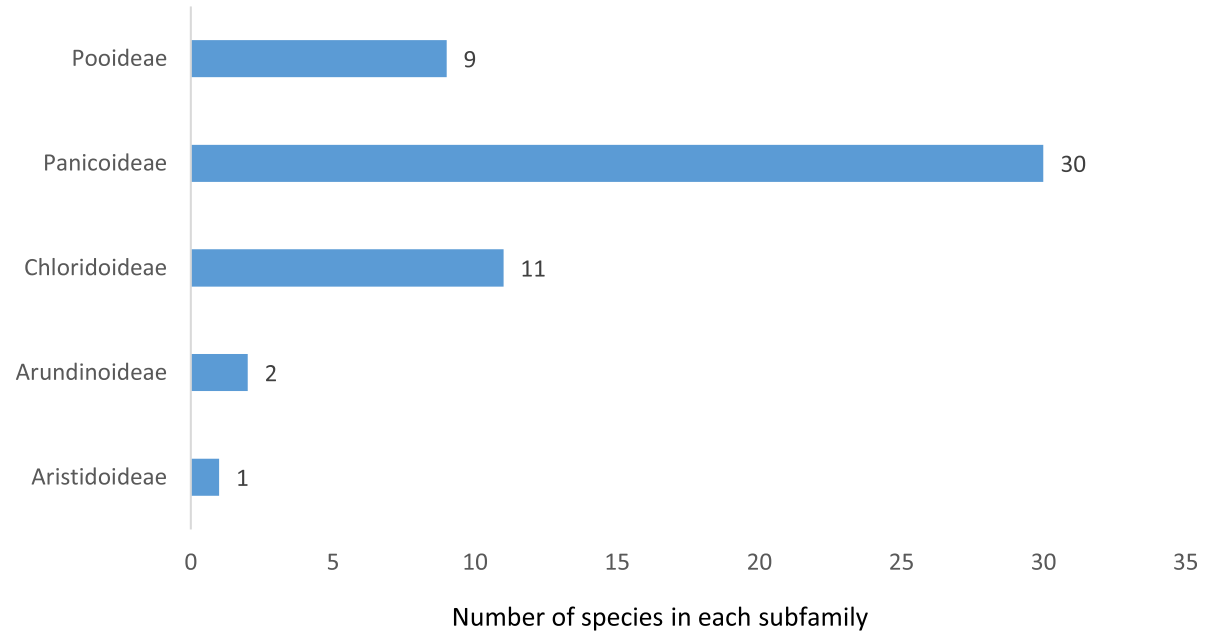

Fig. 3 Number of fodder grass species in each subfamily

d) Graphical illustrations

Microsoft Excel was used to convert selected data items into different types of graphical illustrations.

\section{Results and discussions}

\section{Demography of study area}

The informants of this study were divided into 3 major age groups i.e. $25-35$ years, $36-50$ years and
51-65 years. The maximum number of informants was local shepherds (41\%) because they were the key users of these fodder grasses. It was also observed that in this category most informants were males $(84 \%)$ and the rest were females (16\%). Similarly, in farms there were more men (72\%) than women (28\%). The less number of females as shepherds and farmers showed the cultural pattern of the study area where females were not expected to work in an outdoor environment in this region. Therefore, much

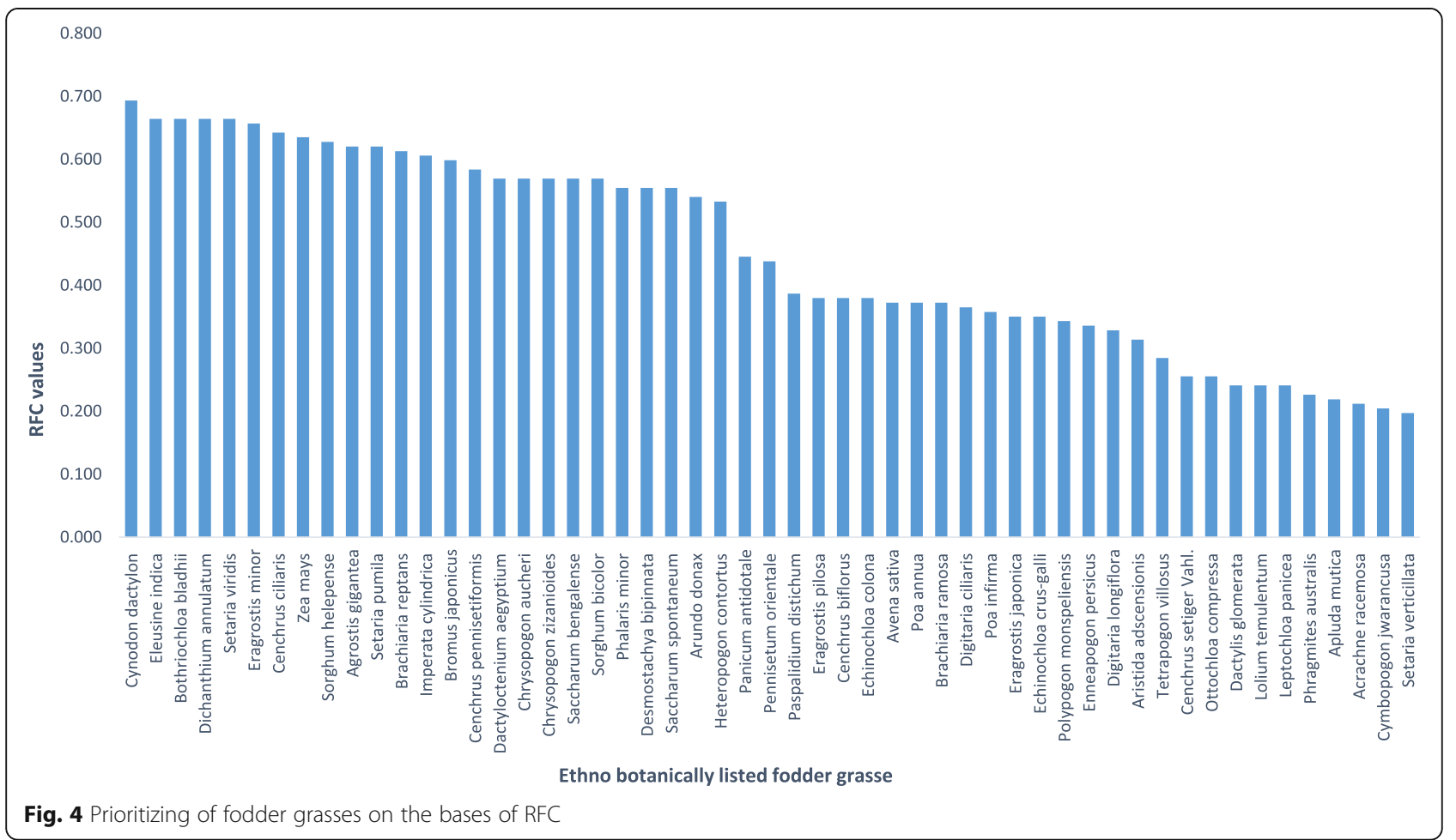




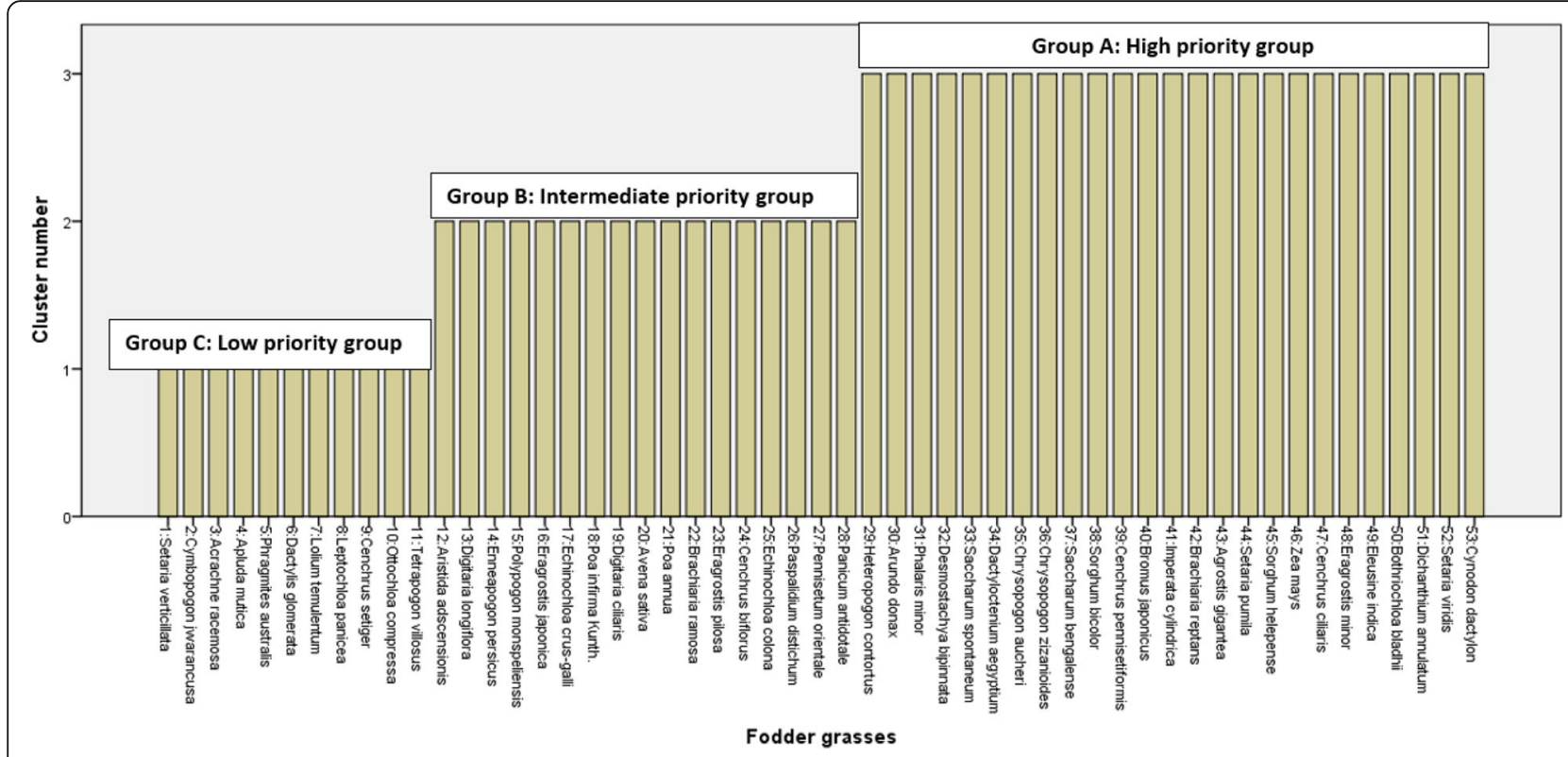

Fig. 5 Cluster analysis for grouping of ethno botanically used fodder grasses

higher $(60 \%)$ number of females was recorded for the category of domestic animal caretakers (Table 1). Regarding their education level, most respondents had completed either 5 years of primary $(70 \%)$ or 8 years of middle $(21 \%)$ level education and a few with no education $(7 \%)$ alongside $2 \%$ with incomplete education (Fig. 2). The animal care takers working in farms were different from the domestic animal care takers in terms of their education. Most of those had 8 years of education with additional training in animal handling and hygiene control measures. It was interesting to note that almost all the informers who were relying on wild grasses as a fodder for their animals, were financially not very sound. Therefore, one of the possible reason for them to utilize these grasses, could be that these grasses were a cost free fodder resource for them to use as a feed for their ruminant animals.

\section{Taxonomic diversity of fodder grasses}

This study revealed that ruminants of Central Punjab Pakistan were fed on a diversified range of wild grasses. As expected, the grass types and their availability did vary between and within the 3 agro-ecological zones of Central Punjab. However, no distinction for this variation was made between these zones when assessing the data for this comprehensive report on 53 ethnobotanical fodder grasses of Central Punjab, Pakistan (Table 4). It appeared during the taxonomic identification process that all of these documented fodder grass species were members of the family Poaceae which is well known for its fodder significance. The value of Poaceae family as fodders is recognised by various ethnobotanical studies from various regions such as those in Africa, India China and even in the lesser Himalayan and Thal dessert of Pakistan [7, 24-28] These ethno botanically listed species belonged to 39 genera which had links with 8 different tribes and 5 subfamilies i.e. Aristidoideae (Aristideae), Arundinoideae (Arundineae), Panicoideae (Paniceae, Andropogoneae), Chloridoideae (Eragrostideae, Chlorideae) and Pooideae (Aveneae, Bromea). Among these subfamilies, Panicoideae was ranked as the top with 30 fodder members and subfamily Aristidoideae attained the least position because it had only 1 member grass being was used as a fodder (Fig. 3). Similar fodder value of subfamily Panicoideae has been well supported by the literature [29].

\section{Prioritizing fodder grasses on the basis of RFC and PC}

The priority determined by the RFC value of 0.693 to 0.197 showed the variable eminence of grasses as a fodder at different sites of study area (Fig. 4). For the sake of data management and comprehensive analysis of listed fodder grasses, they were clustered into high (A), medium (B) and low (C) priority groups on the basis of RFC (Fig. 5). However, when the groups were closely observed it was found that many of the grasses had the same RFC value even within the same group. So the question about their actual priority level was resolved by 
Table 5 Pairwise comparison for fodder grasses having similar RFC

\begin{tabular}{|c|c|c|}
\hline Fodder grasses & Total gained $\%$ points & Rank \\
\hline \multicolumn{3}{|l|}{ GROUP A (RFC $=0.664)$} \\
\hline Bothiochloa Bladhi & 87.5 & $1 s t$ \\
\hline Dicanthium annulatum & 85.5 & 2nd \\
\hline Setaria Viridis & 84.5 & $3 r d$ \\
\hline Eleusine indica & 84 & 4 th \\
\hline \multicolumn{3}{|l|}{ GROUP B (RFC =0.554) } \\
\hline Setaria pumila & 87 & $1 s t$ \\
\hline Agrostis gigantea & 79 & 2nd \\
\hline \multicolumn{3}{|l|}{ GROUP B (RFC $=0.518)$} \\
\hline Dactyloctenium aegyptium & 89.2 & $1 s t$ \\
\hline Chrysopogon aucheri & 88 & 2nd \\
\hline Chrysopogon zizanioides & 86 & $3 r d$ \\
\hline Saccharum bengalense & 80 & 4th \\
\hline Sorghum bicolor & 79.6 & 5 th \\
\hline \multicolumn{3}{|l|}{ GROUP C (RFC $=0.474)$} \\
\hline Phalaris minor & 92.6 & $1 s t$ \\
\hline Saccharum spontaneum & 90.6 & 2nd \\
\hline Desmostachya bipinnata & 87.3 & $3 r d$ \\
\hline \multicolumn{3}{|l|}{ GROUP D (RFC = 0.379) } \\
\hline Echinochloa colona & 59 & $1 s t$ \\
\hline Cenchrus biflorus & 55 & 2nd \\
\hline Eragrostis pilosa & 54 & $3 r d$ \\
\hline \multicolumn{3}{|l|}{ GROUP D (RFC $=0.372)$} \\
\hline Brachiaria ramosa & 36 & $1 s t$ \\
\hline Avena sativa & 35.3 & 2nd \\
\hline Poa annua & 34.6 & $3 r d$ \\
\hline \multicolumn{3}{|l|}{ GROUP D (RFC $=0.35)$} \\
\hline Echinochloa crus-galli & 31.3 & $1 s t$ \\
\hline Eragrostis japonica & 30 & 2nd \\
\hline \multicolumn{3}{|l|}{ GROUP E (RFCs = 0.255) } \\
\hline Cenchrus setiger & 27 & $1 s t$ \\
\hline Ottochloa compressa & 29 & 2nd \\
\hline \multicolumn{3}{|l|}{ GROUP E (RFC $=0.24)$} \\
\hline Dactylis glomerata & 30 & $1 s t$ \\
\hline Lolium temulentum & 29.3 & 2nd \\
\hline Leptochloa panicea & 27.3 & $3 r d$ \\
\hline
\end{tabular}

applying PC method and those fodder grasses which had similar RFC were reorganised in their priority order (Table 5).

The RFC of group A (high priority) ranged from 0.693 to 0.533 and this group comprised of 25 grasses (Fig. 5). However, the group B (medium priority) ranged from $0.445-0.314$ with 17 species and group

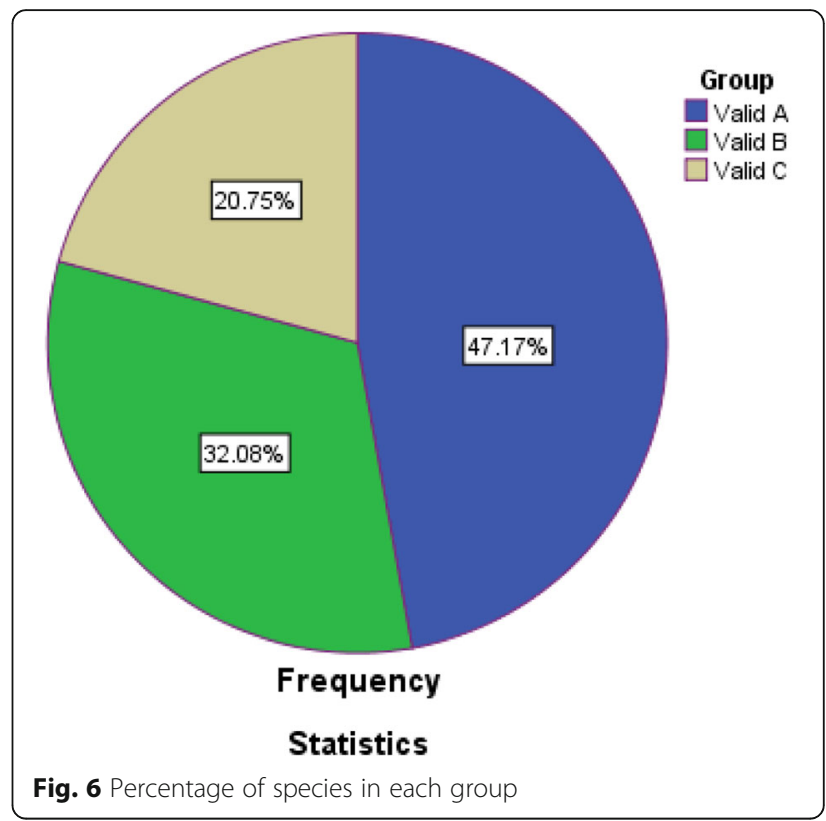

C was extended from $0.285-0.197$ RFC, with 11 species of fodder grasses (Figs. 5 and 6). The higher RFC of top most priority groups (A) depicted that these fodder grasses were probably more dominant in the study area and indigenous people had more familiarity with this group of grasses [30]. So it can be said that all those fodder grass species belonging to high priority group A $(n=25)$ were the most likely and most preferably utilized fodder grasses by the indigenous communities. These fodder grasses were preferred because of their availability, palatability, ability to satisfy animal hunger, ease in availability, positive effects on milk production and shelf life during a dry season (Fig. 7 a-d). Despite the fact that these fodder grasses were valued by local people as a 'quality' fodder, it is essentially required to assess the nutritional potential of these fodder grasses for the sustainability of healthy and efficient livestock industry.

\section{Palatability, part used and feeding methods of listed fodder grasses}

Palatability is the dietary characteristics which can elicit a specific response from an animal [31, 32]. Statistical analysis of palatability frequency analysis showed that all of these fodder grasses were most commonly palatable for cattle i.e. cumulatively $77 \%$ (Table 6). However, the cross tabulated results showed that grasses of group A were palatable to all categories of locally found ruminants i.e. cattle, buffalo, sheep and goat (Fig. 8). The high palatability of group 

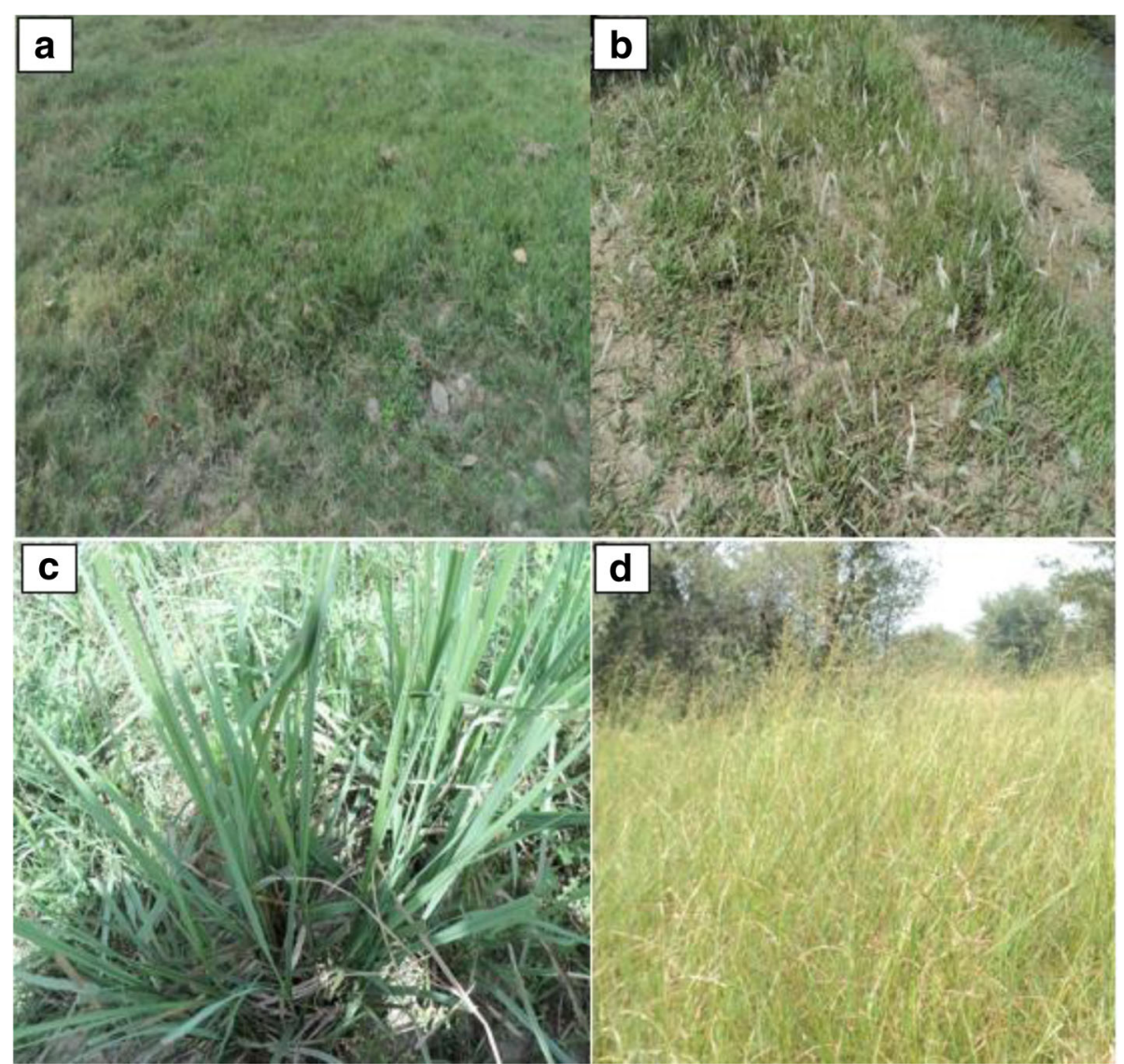

Fig. 7 Examples of some fields with selected members of high priority fodder grasses group e.g. (a) Cynodon dactylon, (b) Imperata cylindrical, (c) Saccharum spontaneum, (d) Sorghum halepense

A members for all types of ruminants indicated their more wide acceptance and significance as highly preferable fodders.

It appeared that most of these fodder grasses were used as a whole plant i.e. $45 \%$, followed by the use of aerial parts $35.8 \%$ and leaves $18.9 \%$ (Table 6). The maximum reported percentage for the whole plant use was probably due to the fact that majority of these grasses were small in height, herbaceous in nature with non woody fibrous and shallow roots which were easily pulled out of soil by the animals. However cross tabulation between priority groups and fodder parts indicated that the group A grasses were mostly eaten by their aerial parts. This is because 9out of 25 grasses (i.e., Sorghum halepense, Desmostachya bipinnata, Sacchrum spontaneum, Saccharum bengalense, Chrysopogon zizanioides, Arundo donax, Sorghum bicolor, Agrostis gigantean, Zea mays) of this group were above the $200 \mathrm{~cm}$ or $400 \mathrm{~cm}$ in heights and these grew well in vigour and density that animal didn't need to pull up the whole plant to satisfy its hunger (Fig. 9).

The current results revealed that overall all the ethno botanically listed grasses were most frequently fed to ruminant animals through ad libitum grazing (cumulatively 96.2\%) (Table 6). Ruminants were probably comfortable with ad libitum grazing due to the fact that they have the natural capability to either avoid the ingestion or utilization of the ingested toxic plants [33, 34]. The provision of grass also plays a valuable role in the production of good quality meat from cattle. Indeed the beef from grass fed animals would be rich in polyunsaturated fatty acids with lower cholesterol content than the beef from animal fed high grain diet [35].It is interesting to report that the members of group A were fed by either grazing or cut and mixed with other type of feeds (Fig. 10). This can be attributed to the high demand and speedy regrowth of these high priority grasses of group A in different regions of this study. 
Table 6 Descriptive statistics: frequency analysis for palatability, parts used for eating and feeding methods and relative abundance of fodder grasses

\begin{tabular}{|c|c|c|c|}
\hline Studied parameters & Frequency & $\begin{array}{l}\text { Valid } \\
\text { percent }\end{array}$ & $\begin{array}{l}\text { Cumulative } \\
\text { percent }\end{array}$ \\
\hline Cattle & 19 & 35.8 & 35.8 \\
\hline Cattle, Buffalo & 5 & 9.4 & 45.3 \\
\hline $\begin{array}{l}\text { Cattle, Buffalo, Sheep, } \\
\text { Goat }\end{array}$ & 16 & 30.2 & 75.5 \\
\hline Cattle, Goat & 1 & 1.9 & 77.4 \\
\hline Cattle, Sheep & 4 & 7.5 & 84.9 \\
\hline Goat, Sheep & 2 & 3.8 & 88.7 \\
\hline Sheep, Goat & 6 & 11.3 & 100.0 \\
\hline Total & 53 & 100.0 & \\
\hline \multicolumn{4}{|l|}{ Fodder part } \\
\hline Aerial & 19 & 35.8 & 35.8 \\
\hline Leaves & 10 & 18.9 & 54.7 \\
\hline Whole & 24 & 45.3 & 100.0 \\
\hline Total & 53 & 100.0 & \\
\hline \multicolumn{4}{|l|}{ Feeding methods } \\
\hline Free grazing & 30 & 56.6 & 56.6 \\
\hline $\begin{array}{l}\text { Free grazing, mixed with } \\
\text { feed }\end{array}$ & 21 & 39.6 & 96.2 \\
\hline mixed with feed & 2 & 3.8 & 100.0 \\
\hline Total & 53 & 100.0 & \\
\hline \multicolumn{4}{|l|}{ Relative abundance } \\
\hline Abundant & 17 & 32.1 & 32.1 \\
\hline Common & 8 & 15.1 & 47.2 \\
\hline Frequent & 10 & 18.9 & 66.0 \\
\hline Occasional & 13 & 24.5 & 90.6 \\
\hline Rare & 5 & 9.4 & 100.0 \\
\hline Total & 53 & 100.0 & \\
\hline
\end{tabular}

\section{Relative abundance of listed fodder grasses}

The results of relative abundance showed that most of the listed fodder grasses were abundant in study area i.e. $32.1 \%$, while least number of fodder grasses was found to be rare (9.4\%) (Table 6). Also an interesting relevance was observed between abundance and priority levels (Fig. 11). The fodder grasses of group A were mostly observed as abundant (17) and common (8) however the medium priority level fodder grasses (B) were recorded as frequent (10) or occasional (7). The lower priority level fodder grasses (C) were customarily in the occasional (6) or rare (5) category. This revealed that the abundance of fodder grasses directly affects their priority of utilization. The grasses which were more abundant in this study area were more preferably used as compared to the others which were less abundant.
Ethno veterinary and other indigenous uses of listed fodder grasses

Since ancient times the human beings are using plant resources for medicinal purpose for not only themselves but also their livestock [36]. This use of plants for animal health care is termed as ethnoveterinary which was evolved alongside animal domestication [37] .The use of these indigenous plants to address multiple health issues of their livestock facilitated animal keepers to decrease the unaffordable cost of certain veterinary medicines [38]. This traditional ethnoveterinary practice is playing a compelling role in maintaining animal production around the globe where rural communities mainly rely on livestock for their livelihood [39-45].

Among all ethno botanically listed fodder grasses, 43 grasses were found with ethno veterinary significance (Table 4). This data showed that local people not only feed their animals on these grasses but also use them to treat the mild health disorders of ruminant animals. Grasses like Bromus japonicus, Phragmites australis, Cynodon dactylon, Desmostachya bipinnata, Eleusine indica, Eragrostis minor were used to treat the multiple digestive disorders like dysentery, constipation and flatulence problems. However, some served as antiseptics e.g. Arundo donax, Brachiaria ramose, Sorghum bicolor, Panicum antidotale and Chrysopogon zizanioides. The reported ethnoveterinary uses of all grasses were compared with other published data from different regions of Pakistan. Some studies stated similar ethnoveterinary uses for Cynodon dactylon [46, 47] while few documented different ethnoveterinary usages of same grasses like Arundo donax, Saccharum spontaneum, Saccharum bengalense, Sorghum halepense and Zea mays [47-51]. However rest of the fodder grasses never reported for their ethnoveterinary use either in Central Punjab or other regions of Pakistan.

Apart from their ethno veterinary value, 25 grasses were also reported for their other indigenous uses (Table 4). Like majority of them are utilized for thatching or making baskets and to cover the crops for protection from harsh weather such as cold winters (Bromus japonicus, Arundo donax, Phragmites australis, Desmostachya bipinnata, Apluda mutica and Heteropogon contortus). However, Phalaris minor and Cymbopogon jwarancusa were interestingly also used as mouse and mosquito repellents respectively.

\section{Conclusion}

This ethnobotanical study is the first of its kind which not only describes 53 naturally grown indigenous fodder grasses of Central Punjab Pakistan, but 


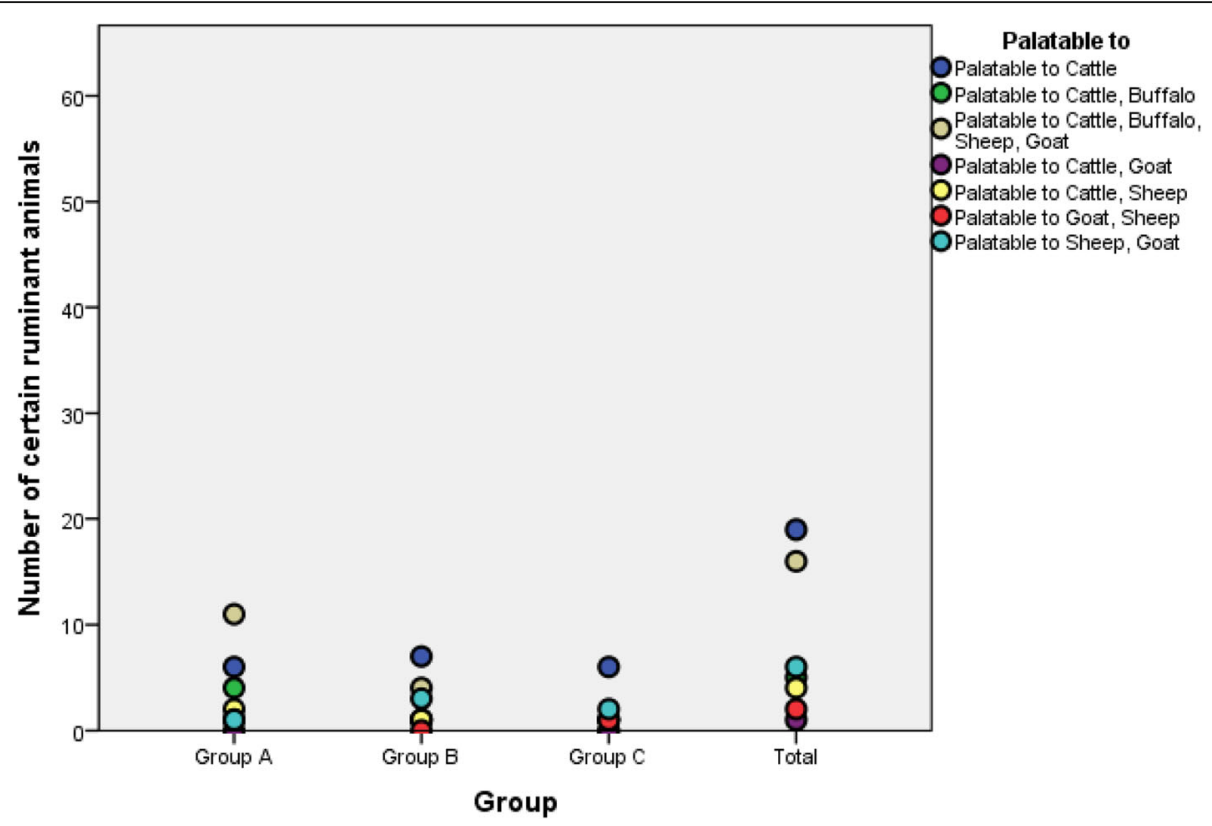

Fig. 8 Association between palatability and priority groups of grasses through cross tabulated method

also provides an inventory which manuscript their local names, most commonly used parts for fodder, diversity in palatability and feeding systems, abundance category and unreported ethnoveterinary uses as well. In addition this research also established 3 fodder grass categories based upon their utilization value. The data analysis highlighted the possible motives behind the greater acceptability ratio of high priority fodder grasses i.e. diversity in their palatability for major ruminant species (cattle, buffalo, goat, sheep), abundant availability in the study area and versatile feeding methods (ad libitum grazing or cut, carry and mixed with other feeds). This data enriched study is not only significant for the conservation of ethnobotanical knowledge but also it may help in facilitating the sustainable livestock feeding

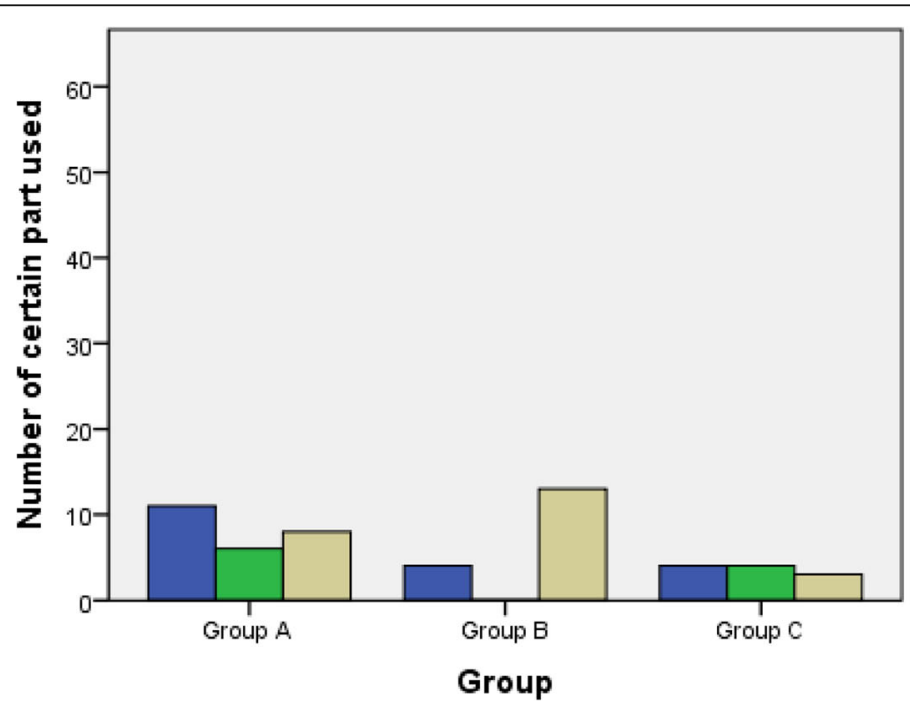

Fodder part

Godder part Aerial

$\square$ Fodder part Leaves

$\square$ Fodder part Whole

Fig. 9 Association between the usage of fodder part and priority groups of grasses through cross tabulated method 


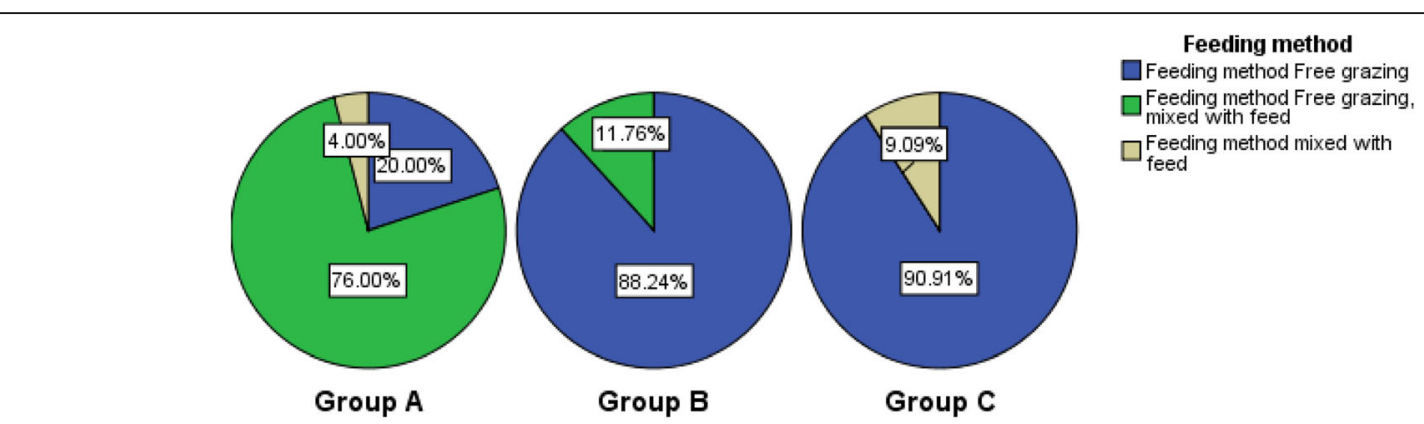

Fig. 10 Association between feeding method and priority groups of grasses through cross tabulated method

for ruminants. Subsequently, the information may play a major role in improving the livelihood of smallholder farmers.

Although these high priority grasses have been used for fodder purpose for centuries by indigenous people, the recorded traditional data were never verified on experimental grounds. So there is a chance that drastic climatic changes in the past centuries would have also altered the soil properties which could ultimately affect the nutritional and medicinal value of these grasses. It is quite possible that actual nutritional as well as pharmacological facts and figures would show entirely a different picture about these conventionally used fodder grasses. Hence, a blend of traditional and scientific knowledge is essentially required to produce worthwhile selection criterion for these fodder grasses. Moreover, if some of these grasses show promising nutritional and pharmacological values then the relevant policy makers should take necessary steps for their enhanced but economical cultivation by providing much needed support to the traditional farmers of the study regions. We believe that further support for the small holder farmers who are working hard despite the challenging environment is needed in this region enriched with traditional knowledge. Otherwise, this natural biodiversity of beneficial grasses could be damaged due to over and unregulated grazing risking the achievement of food security in these and other similar neglected regions of great significance.

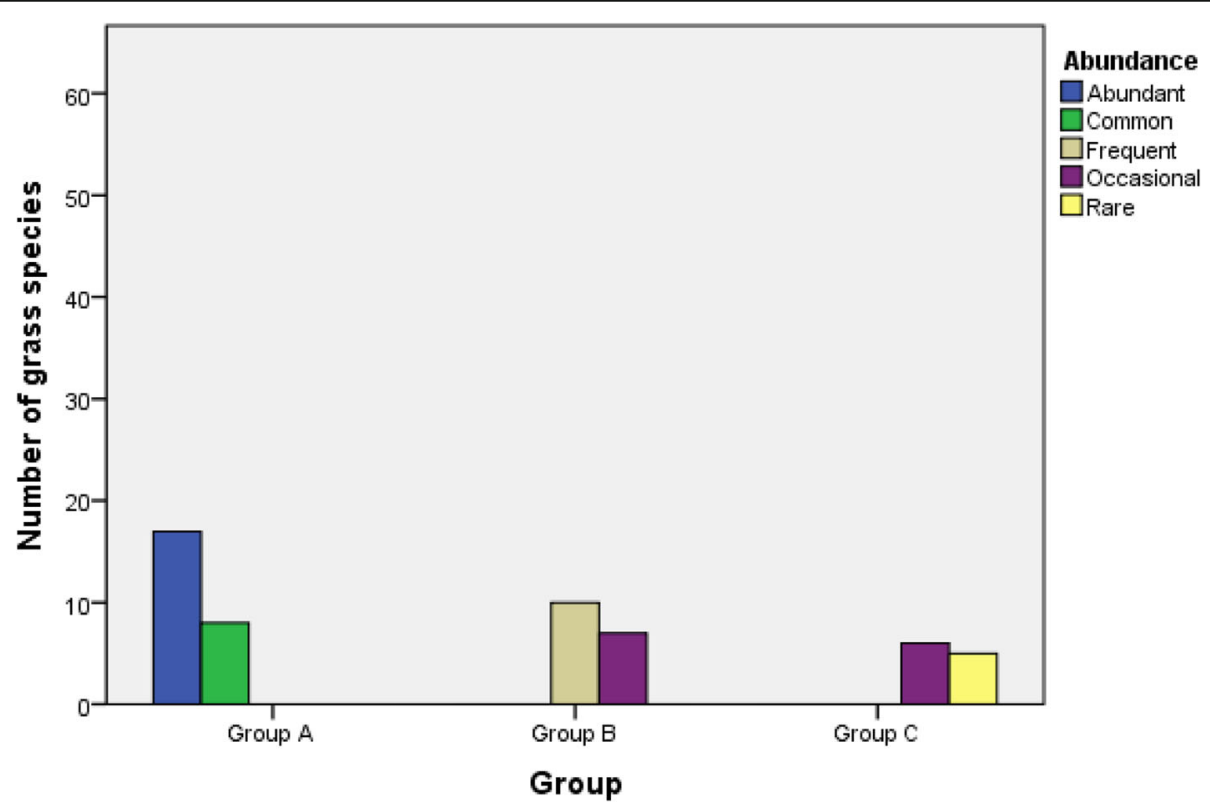

Fig. 11 Association between abundance and priority groups of grasses through cross tabulated method 


\section{Abbreviations}

A: Abundant; Bu: Buffalo; C: Common; Ca: Cattle; F: Frequent; FC: Focal person count; FG: Free grazing; Go: Goat; MF: Mixed with feed; N: total number of informants; NR: Not Reported; O: Occasional; PC: Pairwise comparison; R: Rare; RA: Relative abundance; RFC: Relative frequency citation; Sh: Sheep; SPSS: Statistical Package for the Social Sciences

\section{Acknowledgements}

We acknowledge Dr. Mushtaq Ahmed and Dr. Muhammad Zafar, Department of Plant Sciences, Quaid I Azam University Islamabad for authorizing us to use their herbarium.

Nidaa Harun also thanks Higher Education Commission of Pakistan for travel funding to cover the part costs of processing the data and writing the manuscript alongside Abdul Shakoor Chaudhry at Newcastle University, UK

\section{Funding}

No external funding resources were available for this particular study. All project costs were managed by either personally or resources of LCWU Pakistan.

\section{Availability of data and materials}

Voucher specimens were submitted to the Herbarium of LCWU Pakistan for forthcoming uses (Table 1).

\section{Authors' contributions}

The ethnobotanical survey and fodder grass sample collection was done by $\mathrm{NH}, \mathrm{SS}, \mathrm{KU}$ and FK. NH and ASC did the statistical analysis and wrote the manuscript by providing critical interpretation of the outputs. SS supervised the whole study as well as helped along with FK in the identification of specimens. All authors read and approved the final manuscript.

\section{Ethics approval and consent to participate}

Ethical approval was taken from the chairpersons of local government of al study areas of Central Punjab, Pakistan to visit the specific site and collect fodder grass samples. Also we obtained permission from each informant before conducting the interview. However, all the participants were anonymised and so their personal details are not disclosed in this paper.

\section{Consent for publication}

Not applicable.

\section{Competing interests}

Authors undoubtedly declared that they have no competing interests.

\section{Publisher's Note}

Springer Nature remains neutral with regard to jurisdictional claims in published maps and institutional affiliations.

\section{Author details}

'Department of Botany, Lahore College for Women University, Lahore 54000, Pakistan. ${ }^{2}$ School of Natural and Environmental Sciences, Newcastle University, Newcastle upon Tyne NE1 7RU, UK. ${ }^{3}$ Department of Biosciences, COMSATS Institute of Information Technology, Islamabad 45320, Pakistan.

Received: 26 July 2017 Accepted: 19 September 2017 Published online: 04 October 2017

\section{References}

1. Government of Pakistan-Ministry of Finance, Pakistan Economic Survey (2014-15). 2015. http://www.finance.gov.pk/survey/chapter_10/02_ Agriculture.pdf

2. Wilder A. The Pakistani Voter, Electoral Politics and Voting Behaviour in the Punjab. Karachi: Oxford University Press; 1999. p. 190.

3. Wilson AD, Leigh $\mathrm{JH}$, Hindley NL, Mulham WE. Comparison of the diets of goats and sheep on a Easuarina cristata-Heterodendrram oleifolium woodland community in Western New South Wales. Austr J Ex Agric Anim Husb. 1995;15:45-53

4. Huston JE. Symposium. Dairy goats. Forage utilization and nutrient requirements of the goats. J Dairy Sci. 1978;61:988-93.

5. Grunwaldt EG, Pedrani AR, Vich Al. Goat grazing in arid piedmont of Argentina. Small Ruminant Res. 1994;13:211-6.
6. Khan II. Biodiversity depletion with respect to Human and livestock population in Indian Desert. In: Proc. Rangelands. In a sustainable biosphere (Ed.): N.E. West. 5th International Congress 1995, Salt Lake City Utah. 1996; pp. 286-287.

7. Geng Y, Hu G, Ranjitkar S, Wang Y, Bu D, Pei S, Xu J. Prioritizing fodder species based on traditional knowledge: a case study of mithun (Bos frontalis) in Dulongjiang area, Yunnan Province, Southwest China. J Ethnobiol Ethnomed. 2017;13(1):24-38.

8. Nunes AT, Lucena RFP. dos Santos MVF, Albuquerque UP. Local knowledge about fodder plants in the semi-arid region of Northeastern Brazil. J Ethnobiol Ethnomed. 2015;11(1):12-23.

9. Okoli IC, Ebere CS, Uchegbu MC, Udah CA, Ibeawuchi II. A survey of the diversity of plants utilized for small ruminant feeding in south-eastern Nigeria. Agric Ecosyst Environ. 2003;96(1):147-54.

10. Nahed J, Villafuerte L, Grande D, Pérez-Gil F, Alemán T, Carmona J. Fodder shrub and tree species in the Highlands of southern Mexico. Anim Feed Sci Tech. 1997;68(3-4):213-23.

11. Hussain K, Nisar MF, Majeed A, Nawaz K, Bhatti KH. Ethnomedicinal survey for important plants of Jalalpur Jattan, District Gujrat, Punjab. Pakistan Ethnobot Leaflets. 2010;14(7):807-25. http://opensiuc.lib.siu.edu/cgi/ viewcontent.cgi?article $=1670 \&$ context $=\mathrm{eb}$

12. Zahoor M, Yousaf Z, Aqsa T, Haroon M, Saleh N, Aftab A, Ramazan H. An ethnopharmacological evaluation of Navapind and Shahpur Virkanin district Sheikupura, Pakistan for their herbal medicines. J Ethnobiol Ethnomed. 2017;13(1):27-52.

13. Parvaiz M. Ethnobotanical studies on plant resources of Mangowal, District Gujrat, Punjab. Pakistan AJP. 2014;4(5):364-70. http://ajp.mums.ac.ir/article_ 2158 3327bfa3a6be5b323591a621a5bffc2a.pdf

14. Singh A, Nautiyal MC, Kunwar RM, Bussmann RW. Ethnomedicinal plants used by local inhabitants of Jakholi block, Rudraprayag district, western Himalaya, India. J Ethnobiol Ethnomed. 2017;13(1):49-77.

15. Malik ZA, Bhat JA, Ballabha R, Bussmann RW, Bhatt AB. Ethnomedicinal plants traditionally used in health care practices by inhabitants of Western Himalaya. J Ethnopharmcol. 2015;172:133-44.

16. Ahmad F, Khan MA, Ahmad M, Zafar M, Mahmood T, Jabeen A, Marwat SK. Ethnomedicinal uses of grasses in the Salt Range Region of Northern Pakistan. J Med Plants Res. 2010;4(5):362-9.

17. Martin GJ. In: Walters M, editor. Ethnobotany: A Methods Manual. London: Champan and Hall; 1995.

18. Cotton CM. Ethnobotany: Principles and Applications Chichester. New York: John Wiley and Sons Ltd; 1996.

19. Kellogg EA. Poaceae. The Families and Genera of Vascular Plants, Kubtizki K, editior. Springer, New York; 2014.

20. Wooten G. Draft Key to the Grasses of Okanogan County, Washington. 2008 http://www.okanogan1.com/botany/flora/key-to-grasses-of-okanogancounty-2008-b.pdf

21. Kent $\mathrm{M}$, description $\mathrm{CPV}$, analysis d. A practical approach. London: Belhaven Press; 1992. p. 363

22. Vitalini S, Iriti M, Puricelli C, Ciuchi D, Segale A, Fico G. Traditional knowledge on medicinal and food plants used in ValSan Giacomo (Sondrio, Italy) an alpine ethnobotanical study. J Ethnopharmacol. 2013;145:517-29.

23. Martin GJ. Ethnobotany-A methods manual. Sterling, VA: Earthscan, London; 2004

24. Zizka A, Thiombiano A, Dressler S, Nacoulma BM, Ouédraogo A, Ouédraogo I, Ouédraogo O, Zizka G, Hahn K, Schmidt M. Traditional plant use in Burkina Faso (West Africa): a national-scale analysis with focus on traditional medicine. J Ethnobiol Ethnomed. 2015;11(1):9-18.

25. Bahru T, Asfaw Z, Demissew S. Ethnobotanical study of forage/fodder plant species in and around the semi-arid Awash National Park, Ethiopia. J For Res. 2014;25(2):445-54.

26. Singh V, Gaur RD, Bohra BA. survey of fodder plants in mid-altitude Himalayan rangelands of Uttarakhand, India. J Mt Sci. 2008;5(3):265-78.

27. Abbasi AM, Khan MA, Ahmad M, Zafar M. Medicinal plant biodiversity of lesser Himalayas-Pakistan. Springer Science \& Business. Media. 2011;

28. Chaudhari SK, Arshad M, Ahmed E, Mustafa G, Fatima S, Akhtar S, Amjad MS. Ethnobotanical evaluation of grasses from Thal Desert, Pakistan. Arch Sci. 2013;66(5):248-55

29. Gaur H, Pankaj S. Forage crops and grasses. In: Handbook of Agriculture; 2009. p. 1357

30. Amjad MS, Faisal QM, Ahmad I, Khan SU, Chaudhari SK, Malik NZ, Khan AM. Descriptive study of plant resources in the context of the ethnomedicinal 
relevance of indigenous flora: A case study from Toli Peer National Park, Azad Jammu and Kashmir, Pakistan. PLoS One. 2017;12(2):1-31.

31. Gherardi SG, Black JL. Effect of palatability on voluntary feed intake by sheep. 1. Identification of chemicals that alter the palatability of a forage. Aust J Agric Res. 1991;42:571-84.

32. Church DC. The Ruminant animals. In: Digestive physiology and nutrition. Prospect Heights, IL: Waveland Press; 1993.

33. Provenza FD, Villalba JJ, Dziba L, Atwood SB, Banner RE. Linking herbivore experience, varied diets, and plant biochemical diversity. Small Rumin Res. 2003;49(3):257-74.

34. Rogosic J. The role of secondary compounds in foraging on Mediterranean rangelands. In: Bouche R, Derkimba A, Casabianca F, editors. New trends for innovation in the Mediterranean animal production. Netherland: Wageningen Academic Publishers; 2012.

35. Garcia PT, Pensela NA, Sancho AM, Latimori NJ, Kloster AM, Amigone MA, Casal JJ. Beef lipids in relation to animal breed and nutrition in Argentina. Meat Sci. 2008;79:500-8.

36. Khan MA, Khan SA, Qureshi MA, Ahmed G, Khan MA, Hussain M, Ghulam GM. Ethnobotany of some useful plants of Poonch Valley Azad Kashmir. J Med Plants Res. 2011;5(26):6140-51. http://www.academicjournals.org/ journal/JMPR/article-full-text-pdf/B580DD421550

37. Moreki JC. Documentation of ethnoveterinary practices used in family poultry in Botswana. Vet World. 2013;6(1):18-21.

38. Hoareau L, Da Silva EJ. Medicinal plants: a re-emerging health aid. Electron J Biotechnol. 1999;2(2):56-70. http://www.ejbiotechnology.info/index.php/ ejbiotechnology/article/view/v2n2-2/819

39. Pieroni A, Rexhepi B, Nedelcheva A, Hajdari A, Mustafa B, Kolosova V, et al. One century later: the folk botanical knowledge of the last remaining Albanians of the upper Reka Valley, Mount Korab, Western Macedonia. J Ethnobiol Ethnomed. 2013;9:22-40.

40. Pieroni A. Local plant resources in the ethnobotany of Theth, a village in the Northern Albanian Alps. Genet Resour Crop Evol. 2008;55:1197-214.

41. Leporatti ML, Impieri M. Ethnobotanical notes about some uses of medicinal plants in Alto Tirreno Cosentino area Calabria, Southern Italy. J Ethnobiol Ethnomed. 2007:3:34-9.

42. Guarrera PM, Leporatti LM. Ethnobotanical remarks on Central and Southern Italy. J Ethnobiol Ethnomed. 2007:3:23-33.

43. Guarrera PM, Lucchese F, Medori S. Ethnophytotherapeutical research in the high Molise region Central-Southern Italy. J Ethnobiol Ethnomed. 2008:4:7-17.

44. Montesano B, Negro D, Sarli G, Sarli AD, Laghetti G, Hammer K. Notes about the uses of plants by one of the last healers in the Basilicata Region South Italy. J Ethnobiol Ethnomed. 2012;8:15-24.

45. Di Sanzo P, De Martino L, Mancini E, De Feo V. Medicinal and useful plants in the tradition of Rotonda, Pollino National Park, Southern Italy. J Ethnobiol Ethnomed. 2013;9:19-22.

46. Abbasi AM, Khan SM, Ahmad M, Khan MA, Quave CL, Pieroni A. Botanical ethnoveterinary therapies in three districts of the Lesser Himalayas of Pakistan. J Ethnobiol Ethnomed. 2013;9(1):84-104.

47. Tariq A, Mussarat S, Adnan M, AbdElsalam NM, Ullah R, Khan AL. Ethnoveterinary study of medicinal plants in a tribal society of Sulaiman range. Scientific World J. 2014; https://doi.org/10.1155/2014/127526

48. Sindhu Z, labal Z, Khan MN, Jonsson NN, Siddique M. Documentation of ethnoveterinary practices used for treatment of different ailments in a selected hilly area of Pakistan. Int J Agr Biol. 2010;12(3):353-8. http://www. fspublishers.org/published_papers/79762_..pdf

49. Badar N, lqbal Z, Sajid MS, Rizwan HM, Jabbar A, Babar W, Khan MN, Ahmed A. Documentation of ethnoveterinary practices in District Jhang, Pakistan. J Anim. Plant Sci. 2017;27(2):398-406. http://www.thejaps.org.pk/docs/v-27-2/07.pdf

50. Khan MA, Ullah A, Rashid A. Ethnoveterinary medicinal plants practices in district Peshawar, Khyber Pakhtunkhwa Pakistan. Pak J Bot. 2015;47(SI):105-14.

51. Khan MICM, Hanif W. Ethnoveterinary medicinal uses of plants from Samahni valley Dist. Bhimber, (Azad Kashmir) Pakistan. Asian J Plant Sci. 2006;5(2):390-6.

\section{Submit your next manuscript to BioMed Central and we will help you at every step:}

- We accept pre-submission inquiries

- Our selector tool helps you to find the most relevant journal

- We provide round the clock customer support

- Convenient online submission

- Thorough peer review

- Inclusion in PubMed and all major indexing services

- Maximum visibility for your research

Submit your manuscript at www.biomedcentral.com/submit

Biomed Central 